Anna Alberni

ICREA - Universitat de Barcelona

\title{
Guillaume de Machaut at the Court of Aragon, 1380-1430
}

Knowledge of Guillaume de Machaut's literary and musical works is attested since 1380 in the Francophile court of Aragon, where his art exerted an influence that endured well into the fifteenth century. Catalan poets such as Andreu Febrer and Pere Torroella were greatly influenced by Machaut's poetry. This can be seen in the way they adapted the lay and ballade forms, and in the French section of chansonnier Vega-Aguiló (Barcelona, Biblioteca de Catalunya, MSS 7-8), an important witness to the poetry that originated with the troubadours and was fashionable in the Crown of Aragon until the end of the fifteenth century. This article approaches the role of Machaut's poetry and music in the construction of a literary canon in the Crown of Aragon.

On 18 November 1388, Queen Yolande of Bar (1365-1431) wrote to Gaston Febus, Count of Foix (1343-1391), in order to ask him to lend her "un bon libre apellat Guillaume de Meixaut," ("a fine book called Guillaume de Machaut") which as we learn in her letter, had arrived in Foix as a gift from the Duke of Berry, Jean de France (1340-1416). ${ }^{1}$ The relevant extract from this letter, which has been recently discovered, reads:

Part açò, com hajam entès que vós havets un bon libre apellat Guillaume de Mexaut, lo qual vos donà nostre molt car oncle lo duc de Berrí, pregam-vos, car cosí, que·l nos tramettats encontinent.

This aside, as we understand that you have a fine book called Guillaume de Machaut, which our very dear uncle the Duke of Berry gave you, we beseech you, beloved cousin, that you send it to us without delay. ${ }^{2}$

This manuscript can be identified with the Ferrell-Vogüe Machaut manuscript (Cambridge, Corpus Christi College, MS Ferrell $1[V g]$ ), one 
of the most important and early witnesses of Machaut's works (probably copied in the late 1360s and early 1370s), which may have made its way to the Catalan court of John I (r. 1387-1396) and probably remained in the Crown of Aragon until the first years of the reign of Alfonso V the Magnanimous (r. 1416-1458). As Lawrence Earp first proposed, $V g$ can be identified with the "libre apellat Mexaut" recorded in an inventory of King Alfonso in Valencia in $1417 .{ }^{3}$ One letter from John I (1380), five from his wife Yolande of Bar $(1386,1389$, three letters dated 1390) and one from his brother, Prince Martin (1391), evince an interest in Machaut's works amongst the Catalan royal family at a time when the author's complete-works manuscript tradition was still in the making. Of these letters, at least two may refer to $V g$, as Queen Yolande first asks her cousin Febus for a "fine book called Guillaume de Machaut" on 18 November 1388, and then thanks him for a "llibre molt bell e bo de Guillem de Maixaut" ("a fine, valuable book by Guillaume de Machaut" on 18 June 1389). ${ }^{4}$

It has been hypothesized that Febus obtained the manuscript shortly before 1389 as one of the gifts he received upon allowing Jean de Berry to marry Jeanne de Boulogne (1389), who had been in Febus's guardianship for many years. ${ }^{5} \mathrm{Vg}$ was a deluxe gift of considerable pecuniary value and cultural prestige, as were also goldsmiths' work and jewellery, among other objects of the fine and applied arts. These objects served to broker deals and cement alliances at the highest levels of international diplomacy. French poetry and music, whether represented by extremely lavish manuscripts as $V g$ or in the form of a musical repertoire travelling from one court to another, were part of the cultural wealth of the Valois princes, which contributed to the projection of their power in late medieval Europe. The prestige of such cultural wealth in the fourteenthcentury court of Aragon is well accounted for. Indeed, marriage alliances had for a long time placed the House of Aragon in the center of the main southern European political networks. Cultural agency was part of such networks. Many letters from the royal chancery in Barcelona attest how the Aragonese kings played an active role in the dissemination of musical and literary works. ${ }^{6}$ The reception of Guillaume de Machaut's poetry and music in the Catalan court is perhaps the most remarcable evidence of this phenomenon. As I will try to show, Machaut's literary legacy in the Crown of Aragon is not merely a marginal episode in the reception of his works far afield. On the contrary, it stands as a critical chapter of Machaut's textual tradition in itself, one that may offer new insights into the nature of his poetry and music. 
1. Evidence of the direct textual tradition of Guillaume de Machaut's work in Catalonia is presently restricted to two poems contained in a mid-fifteenth century codex (1420-1430), known as the Cançoner Vega-Aguiló: Barcelona, Biblioteca de Catalunya, MSS 7-8 (henceforth, $V e A g){ }^{7}$ This chansonnier comprises the principal extant collection of troubadour verse compiled in the Crown of Aragon in the late medieval period. Machaut's pieces are copied as anonymous cobles esparses (literally sparse or stand alone stanzas) in a folio that serves as a gateway to the French section of the codex, consisting of poems by Oton de Granson, Jean de Garencières, Jacme Escrivà, and another unidentified francophone Catalan poet (or rather, ballade-writer), probably Oliver de Gleu. ${ }^{8}$

In spite of this limited textual tradition, the influence and reputation of Machaut in the Iberian Peninsula was considerable. In a famous passage dedicated to the poet in the Prohemio e carta al Condestable de Portugal, the Marquis of Santillana, Ínigo López de Mendoza (1448-1449), highlights the penetration of French fourteenth-century formes fixes, associated in the minds of contemporaries with musical accompaniment:

los françeses.... 10 n sones....a las sus obras, e cántanlas por dulçes e diversas manteras, e tanto han familiar, açepta e por manos la música, que paresçe que entr'ellos ayan nasçido aquellos grandes philósofos Orfeo, Pitágoras e Empédocles.... Michaute escribió así mismo un grand libro de baladas, cançiones, rondeles, lays, virolays, e asonó muchos d'ellos. (Gómez Moreno 58)

The French...put musical accompaniment...to their works, and sing them in such sweet and diverse ways, and so dear is music to them, that it seems that Orpheus, Pythagoras and Empedocles themselves had hailed from among that race.... Machaut wrote a great book of ballades, chansons, rondeaux, lays, virelais, and he set many of them to music himself.

The presence of French verse in $\mathrm{VeAg}$ is not accidental. Towards the end of the fourteenth century, troubadour monody had lost ground to the ars nova and to the ars subtilior, cultivated in Northern France and on both sides of the Pyrenees. ${ }^{9}$ A fair number of royal letters testify to the interest shown by John I and his entourage toward the more sophisticated polyphonic developments of the time. This enthusiasm is reflected in the growing number of French and Flemish musicians employed by the Catalan court during the 1370 s. ${ }^{10}$ The time spent by 
young Santillana from 1413 to 1418 under the patronage of Trastamara kings (Ferdinand of Aragon and his son Alfonso V, the Magnanimous) gave him an insider's knowledge of the music and poetry appreciated in their courts. It is to him that we owe our historiographical synthesis of the canon of lyric forms imported from France, a canon that corresponds quite precisely to Machaut's grand libro, containing ballades, chansons, rondeaux, lays, and virelais.

Some of these metrical forms were adopted by Catalan poets writing before Ausiàs March (1400-1459). Their works display a fusion of foreign with native forms, as French styles are grafted upon familiar troubadour ones. A good example is offered by the adaptation of the lyric lay and the chanson laiée by Andreu Febrer (1374-1440/1444). One of his poems (Amors, qui tost fér, quant li play, RAO 59,2) draws its opening and closing lines from Machaut's first lay (Loyauté, que point ne delay, L1), which provides Febrer with his rimes and a series of syntactic cues. This demonstrates not only the depth of Febrer's assimilation of Machaut, but it presupposes an audience familiar with French literary and musical traditions. ${ }^{11}$

The other genres cited by Santillana, especially the French ballade, were adapted and reworked by Catalan poets. A comparative analysis of the forms used in both French and Catalan repertoires shows how fourteenth-century French poetry, frequently set to music, functions as a repository of models of meter and diction freely adapted by Catalan poets. The development of this influence is particularly visible in the late fourteenth-century work of Gilabert de Pròixida (?-1405), Andreu Febrer, and Jordi de Sant Jordi (?-1424) and extends to the last imitators of Ausiàs March, Lluís de Vila-rasa (c. 1420-1502) and Pere Torroella (c. 1420-1492), who were active at the end of the fifteenth century. ${ }^{12}$

The work of Pròixida, Febrer, and Sant Jordi is characterized by an overt interest in formal variety and genre experimentation which is expressed within the discursive framework of the troubadours' fin'amor. While generally sticking to the genre of the cançó and its kin forms, these poets select and adapt new genres like the French formes fixes through a skillful reworking of well-known metric and versification patterns. In this way, they can underscore a borrowing amongst a set of stylized conventions that goes back to the troubadours and the trouvères, or build a new text on the basis of allusion and imitation. The main triggers that set up this "new" Catalan poetry were Guillaume de Machaut's mastery of the art of grafted song and his tendency to dwell on a rhetorics of the sentimental, which some of his followers, like Oton de Granson (c. 1345-1397) and Charles d'Orléans (1394-1465), took to extremes. 
Indeed, contact with Guillaume de Machaut's works resulted in the relentless translatio of the topics and themes of the old troubadours' love song into a new diction, whereby Catalan poetry opened to a new syntax of sentimentality. This must have been perceived by contemporary Catalan audiences as an important break with their "natural" Occitan troubadour past. The adressees of this new poetry, impregnated as they were with the French songs that were being performed at court, were definitely able to grasp the allusions and in some cases even identify their models, especially if those could be remembered through the melodies of refrains and dance songs.

Thus Catalan poets would insistently dwell on the use of certain keywords and syntactic structures that in late fourteenth-century French poetry can be considered discursive cues, particularly in Machaut and Grandson's works, as Marta Marfany has shown. ${ }^{13}$ The influence of Machaut's first-person voice and narrative can also be traced in the literary self-portrait drawn by Jordi de Sant Jordi in one of his well-known cançons (D'aver lo nom e lo dret tall d'aimia, RAO 164,4). In this song, the poet depicts himself as an insignificant individual who is embarassingly "small, short and ugly" as he stands in front of his lady: "car suy petits e curts, d'àl fisomia" (v. 36). The topos of self-dimming and rusticitas is expressed here in a formula that reads very closely to the one used by Guillaume de Machaut in his Voir Dit:

Et se je estoie en vostre presence, je porroie bien querir ce que je ne vorroie mie avoir. Et voicy la cause: je suis petis, rudes et nyces et desapris, ne en moi n'a scens, vaillance, bonté ne biauté par quoi vos doulz yeus me deüssent veoir ne regarder. Et aussi je ne sui dignes de penser a vous. (Machaut, "Voir Dit," l'amant, lettre VI)

\section{TRANSLATION}

2. Indirect manuscript tradition of Guillaume de Machaut in the Crown of Aragon includes an anonymous chivalric romance written in Middle French in the late fourteenth century, the Roman de Cardenois. This work plays a crucial role to provide evidence of Machaut's indirect textual tradition, because it contains ten lyric insertions from the works of Machaut that are incorporated into the main narrative. Two of those pieces are copied in $\mathrm{VeAg}$. Considerations on the origin, context, and dating of the romance may open up questions concerning the relationship between the extant Machaut manuscripts and the sources of the anonymous author, as well as on the relationship of the romance with 
the other textual source of French poetry copied in Catalonia, the $\mathrm{VeAg}$ codex. ${ }^{14}$ The fourteenth-century chivalric feuilleton that unfolds in the Roman de Cardenois, starring a shy and desperate lover who suddenly decides to wear black because his lady has rejected him, recalls the discursive tradition of the poetry described above. This discursive tradition is dominated by the same low spirits that we find in the songs of one of the first Catalan ballade composers, Gilabert de Pròixida, all of whose remaining works are copied in $\mathrm{VeAg}$.

Both the author's identity and the title of the romance are open to conjecture, as such details are not mentioned in the text. The story has been even attributed to Machaut himself, which is perhaps an alluring hypothesis. However, the poor style and paratactic syntax of the Cardenois do not fit well with the wit demonstrated by Machaut in the Voir Dit and elsewhere. ${ }^{15}$ Furthermore, a textual study of the lyrics inserted in the narration shows that the author of the insertions did not have access to an authorized copy of Machaut's works, but relied instead on a branch of the tradition not directly overseen by Machaute 1 refore, in order to support the attribution of this romance to Mach (1, one would have to suppose that, upon writing the novel, Machaut would have extracted his poems from an incomplete copy of his works containing innovations and errors, rather than relying on his own "livre ou je mets toutes mes choses" ("book where I keep all my works"). ${ }^{16}$

In this context, one detail observed by Claudio Lagomarsini is particularly significant. ${ }^{17}$ At least one of the compositions, Diex, Biauté, Douceur, Nature [virelai, V19], was copied from a musical score. This layout of the antigraph's text, copied alongside the music, would have favored the defective copy of the virelai found in the Cardenois (in which the order of lines is muddled), an error that can hardly be ascribed to the author. Additionally, the first lyric insertion makes us cautious about the question of the authenticity. This insertion consists of a collage of two pieces of different metrical forms, a ballade and a lai, merged together as if they were one piece (He gentilz cuers, me convient il mourir [balade, Lo37] + Et pour ce sans nul descour (incipit in other manuscripts: Qui n'aroit) [lai, RF1; str. 12 and 1-11]. Unless new evidence resurfaces, the author of the Cardenois can be assumed to be an enthusiastic fan of Machaut, but cannot be confused with Machaut himself.

The text of the romance is preserved in a single manuscript once belonging to the personal collection of the Marquis of Santillana, now housed in the Biblioteca Nacional de España in Madrid, MS 10264 
$(M n)$. The manuscript may be dated provisionally

Detween 13631365 (the date of the Voir Dit, which the anonymous author knew) and 16 December 1400, when a register of the chancery of King Martin I (r. 1396-1410) records a note that had been overlooked until recently. In this memorandum the King commands his chamberlain, Miquel Embrun, to request from his son Martin I of Sicily a "libre de Tardanoys."18

This reference is intriguing for several reasons. First, it is uncommon to find a romance referenced in a list of sundry administrative duties. Second, what would the name of the protagonist be: Cardenois or Tardenois? Answering this question is crucial in order to clarify a palaeographical uncertainty that is central to the preparation of a new edition of the text. In the only manuscript transmitting the work, the confusion between lower-case $c$ and $t$ is constant, but it is also clear that, for the copyist of the manuscript, the name was Tardenois, as the paleography of other capital Ts in the manuscript confirms. In our forthcoming edition, however, we decided not to change the hero's name. Internal evidence suggests that the name might derive from Cardona, a town northwest of Barcelona that was the historical seat of a comital dynasty related to the Royal House of Aragon. ${ }^{19}$ There is additional internal evidence supporting this link between the name of the protagonist and the Cardonas: 1) the romance mentions a lady, "Alienor of Servillon," who can be identified with Alionor de Cervelló, the daughter of Ramon de Cardona married to Hug de Cervelló since 1338 (probably the same "Alienor de Cardona" featured in the Barcelona episode of Jean de Saintré); 2) the fruit trees found in the palace garden of Cardenois' father, called tourongiers, refer to Mediterranean horticulture and use an Arabism that is common in Catalan but otherwise unknown in French-the French taste for orangeries is not attested before the sixteenth century; 3) the name of the heroine, Passebeauté, coincides with a senhal used by Andreu Febrer, one of the key literary figures of the period spanning between the reign of John I and the early part of Alfonso the Magnanimous's times. Febrer wrote a poem dedicated to a group of ladies from the court of the Cardonas (Si.n lo mon fos gentilesa perduda, RAO 59,15), also copied in $\mathrm{VeAg} .{ }^{20}$ Still further evidence includes: 1) the only textual witness to the romance, $M n$, preserves various Catalan texts copied by other hands; 2) the language of the Cardenois presents Occitanisms and Franco-Provençalisms, which make us think of a Southern French copyist, perhaps from the Languedoc; ${ }^{21} 3$ ) the textual transmission of the Machaut quotations in the narrative shows that the source belonged to a textual branch circulating in the Crown of Aragon. ${ }^{22}$ 
In any case, the mention of the romance around 1400 confirms its presence in Catalan royal circles at a date that is roughly contemporary with the composition of the work. This is coherent with what we know about the circulation and royal patronage of the manuscripts containing Machaut's works in Catalonia by the end of the fourteenth century, and with the influence Machaut exerted at that time on Catalan poetry.

3. The anonymous author of the Cardenois borrows from Machaut his description of the heroine, Passebeauté, in a prose passage which draws heavily on episodes from the Jugement $d u$ Roy de Behaingne (before 1346) and the Remède de Fortune (before 1357). ${ }^{23}$ However, as it has been mentioned earlier, the most interesting characteristic of the Roman de Cardenois is that it preserves twelve French lyric texts, of which at least ten are by Machaut. ${ }^{24}$

Of the ten pieces attributable to Machaut, four ballades derive from the Loange des dames (the name customarily given to the section of lyric poetry not set to music in the complete-work manuscripts of Machaut): 1. He gentilz cuers, me convient il mourir (balade, Lo37; the following lai is copied without a textual break); 2. Doulce dame, vous ouciez a tort (balade, Lo73, lines 1-2 only); 3. Amis mon cuer et toute ma penssee (balade, Lo220; 1st stanza also in VeAg); 4. Quant vrais amans de sa dame se depart (balade, Lo216, only line 1). A virelai and a complainte, from the Voir Dit (c. 1365): Je ne me puis saouller (V33 = VD11) and Or soit ainsi com Dieux ha ordonné (inc. in other manuscripts: Mes dous amis) (Cp5 = VD15: 1388-1393, last 6 lines; also in VeAg). ${ }^{25}$ As already noted, the lay from the Remède de Fortune is merged with the first balade, appearing as a single aberrantly structured poem, and copied without music. The three remaining pieces comprise a virelai, a complainte, and another balade, which do not belong to the Loange: Diex, Biauté, Douceur, Nature (V19), Mon cuer, m'amour, ma dame souveraine (Cp6, line 1 only), Riche d'amour et mendiant d'amie (B5). We also find two anonymous lyric poems copied in the main body of the narrative and laid out as prose: 1) Amis, se par ma foulie (which is part of an anonymous virelai laid out on the page as prose; also in $\mathrm{VeAg}, \mathrm{Pa}$, Jean Froissart's Joli buisson de jeunesse, and Évrart de Conty's Problemata and Echecs amoureux ${ }^{26}$ ), and 2) De la plus... $($ lus bel regart (an unidentified lyric composition of 6 lines, laid out as prose).

In addition, the prose of the novel is peppered with more or less explicit quotations of Machaut verses. ${ }^{27}$ This prose is mainly an imitation of the hybrid style and mixture of genres in the Voir Dit, including the exchange of amorous correspondence, the dramatisation of the role of 
the reader, and the focus on the narration of the events rather than on the events themselves.

As I have indicated in brackets above, three of the pieces inserted in the romance are also copied in VeAg. The presence of two stanzas of Machaut in this chansonnier, which are included in the Roman de Cardenois in the form of arias recited by the two female protagonists, represents a remarcable extension of the reception of Machaut's works outside France in the fifteenth century. One way of explaining this textual tradition is as a progressive dismantling of what the author had conceived as an ordered whole ("le livre ou je mets toutes mes choses"). This process parallels the one observed in other late witnesses of Machaut's works, such as the chansonnier $\mathrm{Pa}$ (Philadelphia, University of Pennsylvania Library, MS 902 [olim Fr. 15]), which I will discuss in more detail below. The reception of this late manuscript tradition of Machaut in Catalonia might have played an important role as a textual and stylistic bridge between the fourteenth-century French lyric canon and later Hispanic poetry.

In $\mathrm{VeAg}$ we can read the first stanza of the ballade Amis mon cuer e toute ma pensee (Lo220), and the last six lines of a complainte entitled Or soit ainsi com Dieux ha ordonné (Cp5). The anonymous poem Amis, se par ma foulie, was placed between these two texts, and has been identified by Pierre-Yves Badel as the first part of a longer virelai inserted in Jean Froissart's Joli buisson de jeunesse, according to Froissart's own report composed circa 1353 by a lady in Picardy. ${ }^{28}$ All three pieces were transcribed on a single folio in $V e A g$ (f. 147r) which precedes a section exclusively made of French ballades, including Oton de Granson's Les cinq balades ensuivans (copied without attribution to Granson), followed by Jean de Garencières' Enseignement $d u$ dieu d'amours, and Granson's longer poems. ${ }^{29}$ The outline below summarizes the order of the poems in both sources:

Roman de Cardenois $(\mathrm{Mn})$

1. Amis se par ma foulie (anonymous virelai)

2. Or soit ainsi com Dieux ha ordonné (Machaut: complainte, Cp5, vv. 33-38)

3. Amis mon cuer et toute ma pensse (Machaut: balade, Lo220)

$\operatorname{VeAg}$ (MS 8, f. 147r)

3. Amis mon cuer e touta ma pensea (Machaut's Lo220: only 1st stanza) 
1. Amis si pour ma folbia (anonymous virelai: same lines as in the Cardenois, with variant readings but same mise en texte, different from that found in Froissart's Joli buisson de jeunesse and in $\mathrm{Pa}$ )

2. Or soyt eynsi con Diu ha ordoné (Machaut's Cp5, vv. 33-38: same lines as in Cardenois)

The three French stanzas copied without attributive rubric in $V e A g$ stand out for one reason: in all three, the lyric I corresponds to the voice of a woman's lament, in the style of the chanson de femme. The genres-a balade, a virelai (at least in its original form) and a complainte-do not take us far from the musical and poetic items specified by the Marquis of Santillana in his Probemio e carta. These are essentially the same lyric forms to which the Catalan infante John, the future "Musician King," also refers in a well-known letter of 1380 to his brother, the future King Martin I:

Car frare: sapiats que, lo jorn de la festa de ninou prop passada, nós entrevenents alscuns dels nostres xantres, fahem $\cdot \mathrm{i} \cdot$ rondell notat $\mathrm{ab}$ sa tenor e contratenor e ab son cant, traslat del qual vos trametem dins la present entreclús, pregants-vos, frare car, que·l cantets e.l façats cantar e que.l mostrets $o \cdot 1$ façats mostrar a tots aquells qui us serà semblant. E si vós ne altre alcú qui ab vós sia vol fer viralay o rondell o ballada en ffrancès, enviats-la'ns quan feta sia, car nós la us trametrem notada ab son so novell. ${ }^{30}$

Dear brother: know that during the celebration of this past's New Year's Day, we, with the help of some of our singers, composed a rondeau with two parts for tenor and contratenor and cantus. We are sending you a transcription of this piece alongside the present epistle, and beseech you, dear brother, that you sing it and have it performed and that you show it or have it circulate among all those you see fit. And if you, or any other of your company, should wish to write a virelai, rondeau or ballade in French, do send it to us when it is ready, for we will return it to you with a new musical score.

Aside from the two pieces by Machaut, the anonymous little poem, Amis se par ma foulie, is relevant because both Cardenois and VeAg transmit the same mise en texte of the virelai (different from Froissart's version in Joli buisson de jeunesse, incipit Par un tout seul escondire). This is also copied, in a form closer to Froissart's, in $\mathrm{Pa}$ (f. $41 \mathrm{vb}$ ), which is an important codex for the textual tradition of Granson and one of the clearest examples of the "deconstruction" of the complete works of Machaut at the turn of the fifteenth century. ${ }^{31}$ 
The similar ordering of the three texts copied both in $\mathrm{VeAg}$ and Cardenois, the peculiar extracts from the complainte (reduced to its final six lines), and the specific form of the virelai show that the two witnesses share a common source, which we might call $\mu$. In particular, if we consider the original form of the virelai reconstructed by Badel, it is significant that both Cardenois and $\mathrm{VeAg}$ insert the same spurious verses. A detailed textual analysis discards the possibility that Cardenois be a direct copy of $\mathrm{VeAg}$ (or viceversa): the rewriting of the virelai must proceed from a common source to both. Some readings, ind bring $\mu$ close to $\mathrm{Pa}$, thus allowing us to posit a third witness. ${ }^{32}$ The text of Machaut's complainte Cp5 also clearly affiliates VeAg to the Roman de Cardenois: the Catalan chansonnier and $M n$ are the only Machaut witnesses that omit the first part of the text and preserve only the last six lines of the poem.

Strikingly, the Ferrell-Vogüé manuscript begins at $\mathrm{f}$. $34 \mathrm{r}$ with the same six lines and the first half of the complainte on the preceding folio. The genetic relationship of what we may term the "Vogüe constellation" is manifest also in the ordering of the poems. In $V g$, as in the other manuscripts of this branch of the family, the ballade Amis mon cuer is the last in the series of ballades from the Loange des Dames. After that a section follows in which the first female-voiced text is our complainte $\mathrm{Cp} 5$, Or soit ainsi. This "Vogüe family or constellation," which includes, in addition to the codex descriptus $B, E$ (derived from $B)$, and $\mathrm{Pa}$, may have produced a source available in the Catalan milieu where the Roman de Cardenois and VeAg were compiled. ${ }^{33}$ It is in fact likely that the Ferrell-Vogüe codex played an important role in the transmission and circulation of Machaut's literary legacy in the Crown of Aragon. This idea is supported by several pieces of evidence, including the genetic relationship between $\mathrm{Vg}$, the Roman de Cardenois, and $\mathrm{VeAg}$, as discussed above.

Several codicological features encourage us to speculate on the passage of the manuscript through the Crown of Aragon. First, the musical section of $V g$ opens with the first of Machaut's lays, Loyauté que point ne delay (L1), imitated by Andreu Febrer in his lay Amors qui tost fer quant li play (RAO 59,2), as already noted. ${ }^{34}$ Andreu Febrer is documented from 1393 in the service of John I and later on serving Martin I, Alfonso V, and the widowed Queen Yolande. If, as it must be assumed, $V g$ is one of the "Meixaut" (D) ntioned in the Queen's letters, the Catalan poet might have had direct and easy access to L1. Febrer's knowledge and literary reworking of this composition is of noteworthy relevance to later Catalan and Hispanic poetry. For instance, it is central to the adaptation and subsequent development of the chanson laiée. 
Second, a coat of arms on the front cover of the manuscript allows for a tentative identification of the blazon of Maria of Castille, the wife of Alfonso the Magnanimous, into whose library $V g$ may have found its way after the King moved to Naples (1435). The remains of the pales of Aragon are clearly visible on the left portion of the blazon. The right segment is severely damaged, but experts have already suggested the arms of Castille and Leon. ${ }^{35}$

Textual analysis of the lyric compositions shared by $\mathrm{VeAg}$ and the Roman de Cardenois agrees with what we already knew of the circulation of Machaut manuscripts in Catalonia in the fourteenth and fifteenth centuries. One of these manuscripts is in all likelihood the Ferrell-Vogüe codex, an object to have been surely appreciated in the "musical" and "French" court of John I. As we have seen, the analysis of the probable relationships between the extant witnesses of the Machaut poems copied in Catalonia has proved a crucial tool for reconstructing the history of the tradition and, therefore, of the dissemination of the text. It has furthermore corroborated the existence of a "Vogüé constellation" from which the Roman de Cardenois and the VeAg might have drawn their lyric compositions.

To conclude, the Roman de Cardenois and the French stanzas copied in $\mathrm{VeAg}$ can be both considered relevant events in the reception of Machaut's works in Catalonia, and witnesses to the progressive dismantling and reordering of his livre, as Deborah L. McGrady has demonstrated. The genetic relationship between Cardenois and $\mathrm{VeAg}$, on the one hand, and the reference to the romance in King Martin's record of 1400 , on the other, lead us to locate at least one stage of this process in the Crown of Aragon towards the end of the fourteenth century, a time when the prestige of French literature and music held the Catalan élites in their thrall.

\section{Notes}

1. Some aspects of this research were first developed in my previous paper "Machaut's Literary Legacy in the Crown of Aragon: the Catalan Chansonnier Vega-Aguiló and the Anonymous Roman de Cardenois." I am grateful to Nicola Morato and Dirk Schoenaers for permission to publish them here. I am also grateful to Yolanda Plumley and Lawrence Earp for their feedback on some of the aspects discussed in this paper. My work has benefitted from the European Research Council Independent Starting Grant project The Last Song of the Troubadours: Linguistic Codification and Construction of a Literary Canon in the Crown of Aragon (14th-15th centuries) (FP7 2009-2013-241070). It has 
also benefitted from a Spanish Government grant with the project entitled $\mathrm{La}$ poesía francesa en las cortes de la Corona de Aragón (s. XIV-XV): recepción y circulación (FFI 2014-54844-P).

2. Barcelona, Arxiu de la Corona d'Aragó, Reg. 2053, f. 84v. I first presented Yolande's letter at the International Conference The Works of Guillaum de Machaut: Music, Image, Text in the Middle Ages (University of Exeter, 29-30 April 2013), organized by Yolanda Plumley. The relevant extract has been published by Earp, "Vg to 1389" 38, in his introductory study to the facsimile edition of the codex. It has also been cited by Torró, "La poesia cortesana" 263.

3. Earp, "Machaut's Role" 478, n. 35.

4. All relevant extracts of the letters from the Arxiu de la Corona d'Aragó, except for the one recently discovered, are cited and commented in Alberni, "El Roman de Cardenois" 100-08 (with a new edition of some of the texts). Earp, "Vg at the Court of Aragon" gives a complete and detailed account of all the letters, with new insights on the "Catalan history" of $V g$ until 1458.

5. See Earp, "Vg to 1389." According to François Avril, the exquisite miniatures of the Ferrell-Vogüe manuscript were painted in Paris for a prestigious patron attached to the court of Charles V. This would make Jean de Berry, Queen Yolande's uncle, a prime candidate as the first owner of the chansonnier.

6. Cf., at least, Rubió i Lluch, Documents.

7. On the contents, structure and context of $\mathrm{VeAg}$, see Alberni, «Intavulare».

8. Cf. Marfany, "Les balades franceses"

9. On the so-called avantgarde condition of the ars subtilior in the southern courts of Foix-Bearn, Berry, Navarre and Aragon, see Plumley, "An 'Episode in the South'?."

10. Gómez Muntané in La música en la casa real edits and analyzes an important collection of documents from the Arxiu de la Corona d'Aragó (Barcelona) specifically dedicated to the patronage of music by the Aragonese Kings. Subsequent publications by the same author and other scholars have enriched and refined this pioneer study. For a complete bibliography, see Gómez Muntané, La música medieval en España, and Cingolani, "Joglars, ministrers i xantres." Stefano M. Cingolani and I are currently working on a Diplomatari collecting notices on minstrels, jongleurs, troubadours, musical instruments and poetic manuscripts located in the Arxiu de la Corona d'Aragó (from the thirteenth to the fifteenth century). This research is part of the ERC-CoG-2017-772762 project Iocultaor su mimus: Performing Music and Poetry in medieval Iberia (MiMus), directed by Alberni at the Universitat de Barcelona.

11. For a general analysis on the influence of French literature on Catalan poetry, see Pagès, La poésie française en Catalogne. Pagès's work is revised by Lluís Cabré, who offers important new insights on the subject, in Cabré, "Los enuigs de Jordi de Sant Jordi i l'adaptació del lai lyr $n$ nd "El conreu del lai líric a la literatura catalana medieval." On Febrer's lar, Febrer, Poesies. RAO stands for "Repertori d'Autors i Obres" in Parramon i Blasco, Repertori mètric. For references to Machaut's works, I will follow the abbreviation system adopted in Earp, Guillaume de Machaut. 
12. See Marfany, "La influència de la poesia francesa" and also Torró, Sis poetes del regnat d'Alfons el Magnànim, on the poems of Lluís de Requesens, Bernat Miquel, Martí Garcia, Rodrigo Dies, Lluís de Vila-rasa, and Francesc Sunyer.

13. For example, the use of a clause formed by an adjective + prep de or simply an adjective in apposition, placed at the opening of a pièce or a stanza (Andreu Febrer, Ay, cors avar, scars, richs de mercè (RAO 59,1, vv. 1-2): "Trist, enguxós, desemat, plen d'esmay, / amorós, bast de tota grieu tristura"; Jordi de Sant Jordi, Desert d'amichs, de béns e de senyor (RAO 164, 5, v. 1)). Cf. Marfany, "La influència de la poesia francesa."

14. This section of the paper is much indebted to the forthcoming edition of the roman by Claudio Lagomarsini, Fabio Zinelli, and Anna Di Fabrizio. See also the previous edition of the Roman de Cardenois by Marcello Cocco.

15. Machaut's authorship has been suggested by Valero de Holzbacher, "En réhabilitant la mémoire.”

16. On Machaut's role in the production of copies of his works, see Williams, "An Author's Role” and Earp, "Machaut's Role." On the authorship of the Cardenois as related to Machaut's manuscript sources, see Lagomarsini, "Il Roman de Cardenois" 109-33, and "Poesia lirica."

17. Lagomarsini, "Il Roman de Cardenois" 120-22.

18. Barcelona, Arxiu de la Corona d'Aragó, Reg. 2299, f. 15v: “Memorial de ço que mossen miquel dambu ha de part del senyor rey d'arago explicar al rey de sicilia en virtut de la creença a ell comanada" ("Memorial of the things that mossen Miquel Dambu has to report to the King of Sicily from his father the King of Aragon, owing to the trust held in him"). The text, first published by Moscati, Per una storia della Sicilia 120-21, is quoted in Zinelli, "Il Roman de Cardenois" 301-02.

19. Both Lagomarsini and Zinelli discuss this palaeographical question and their editorial solution in their forthcoming critical edition of the work.

20. Evidence first provided by Valero de Holzbacher, "Elementos histórico-geográficos."

21. On this hypothesis, see Zinelli, "Il Roman de Cardenois" 341-45, building on Speroni, "Una rilettura."

22. For further development of these aspects, see Alberni, "Guillaume de Machaut" and "El Roman de Cardenois" (regarding the traces (W) haut's works and the Cardenois in Catalan poetry); Lagomarsini, "Il Roman aeCardenois" (for the textual analysis of all of Machaut's insertions in the Cardenois); and Zinelli, "Il Roman de Cardenois" (for a linguistic analysis of the Cardenois, a textual study of the lyrics inserted in the roman and also copied in $V e A g$, and for further details on its historical context).

23. See Machaut, Le Jugement du roy.

24. The lyric insertions are listed and commented by Lagomarsini, "Il Roman de Cardenois" 112-13.

25. For the Voir dit quotation, see Machaut, Le Livre du Voir Dit 156-60. 
26. On this virelai, see below. For incipit quotation in Machaut and citational practice in fourteenth-century French lyric tradition, see Plumley, The Art of Grafted Song.

27. On this specific form of incipital quotation, see Kay, Parrots and Nightingales.

28. See Badel, "Par un tout seul escondire."

29. For the attribution of the first section of ballades to Catalan poet Oliver de Gleu and, in the case of the single ballade Hoiés ores, mon cuer, ce que vueil dire, to Jacme Escrivà, see Marfany, "Les balades franceses."

30. Letter first published by Rubió i Lluch, Documents 283-84 (Barcelona, Arxiu de la Corona d'Aragó, Reg. 1658, f. 108).

31. The first line of the poem is also reported in Évrart de Conty's comment to his translation of the pseudo-Aristotelian Problemata, and in his comment to the Echecs amoureux moralisés, where it is clear that the virelai had been set to music, probably before Froissart's inclusion in his Joli buisson de jeunesse; see Sultan, "Ymagner son chant" 310-11. Notably, in the chansonnier Pa, as in VeAg, Oton de Granson's Les cinq balades ensuivans are copied without attribution. On $\mathrm{Pa}$ as a privileged witness of Machaut's late medieval audience, see McGrady, Controlling Readers.

32. A shorter line in v. 2 and common readings of $\mathrm{VeAg}$ and Cardenois (against Froissart) in vv. 3 and 5. The closeness of our source to $\mathrm{Pa}$ had already been noticed by Badel "Par un tout seul escondire" 379.

33. $\mathrm{Pa}$ seems to have received an important part of its Machaut poems from $E$, and is relevant as much to Oton de Granson's as to Machaut's textual tradition. See Granson, Poésies, and Marfany, "Les balades franceses." Lagomarsini’s thorough textual analysis of all of Machaut's lyric insertions in the Cardenois is consistent with this conclusion.

34. This lay by Machaut opens a new gathering in $V g$ (f. 291r), which according to Friedrich Ludwig was divided into two volumes. The first half would have contained the text, and the second half, the music. The folio where the lay begins is damaged. This might suggest that it once constituted the opening of a separate part of the volume. See Earp, Guillaume de Machaut 84.

35. See Binski and Panayotova, The Cambridge Illuminations 267-68, and Earp, "Vg at the court of Aragon" 66-68. For more illustrations of the arms of Maria of Castille, see Vicens, "Aproximació al món artístic.”

\section{Manuscripts Cited}

Barcelona, Biblioteca de Catalunya, MSS 7-8 (VeAg). <http://mdc.csuc.cat/cdm/ref/collection/manuscritBC/id/118080>

Cambridge, Corpus Christi College, MS Ferrell $1(V g)$. <https://www.diamm.ac.uk/publications/ferrell-vogüé-machaut-ms/>

Madrid, Biblioteca Nacional de España, MS 10264 (Mn). $<$ <ttp://bdh-rd.bne.es/viewer.vm?id=0000048780\&page $=1>$ 
Paris, Bibliothèque nationale de France, MS français 1585 (B). <http://bdh-rd.bne.es/viewer.vm? id=0000048780\&jpage $=1>$

Paris, Bibliothèque nationale de France, MS français $1586(C)$. <https://gallica.bnf.fr/ark:/12148/btv1b8449043q>

Paris, Bibliothèque nationale de France, MS français 9221 (E). <https://gallica.bnf.fr/ark:/12148/btv1b6000795k>

Philadelphia, University of Pennsylvania Library, MS $902(\mathrm{~Pa})$. <http://hdl.library.upenn.edu/1017/d/medren/993559163350368>

\section{Works Cited}

Alberni, Anna. "Intavulare»: Tavole di canzonieri romanzi (serie coordinata da Anna Ferrari): I. Canzonieri provenzali, 11. Biblioteca de Catalunya: VeAg (mss. 7 e 8). Modena: Mucchi, 2006. Print.

—. "Guillaume de Machaut en la tradició catalana dels segles XIV-XV: la suite d'esparses del cançoner VeAg." Translatar i transferir: La trasmissió dels textos i el saber (1200-1500). Ed. Anna Alberni, Lola Badia, and Lluís Cabré. Santa Coloma de Queralt: Obrador Edèndum, 2010. 317-47. Print.

—. "El Roman de Cardenois i l'empremta de Guillaume de Machaut en la poesia catalana medieval.” Romania 130 (2012): 74-108. Print.

- "Machaut's Literary Legacy in the Crown of Aragon: The Catalan Chansonnier Vega-Aguiló and the Anonymous Roman de Cardenois." Morato and Schoenaers 391-410.

— cançó dels trobadors a Catalunya: Text, forma, edició. Barcelona and Rome: Viella, 2016. Print.

Avril, François. "Les manuscrits enluminés de Guillaume de Machaut: Essai de chronologie." Guillaume de Machaut, poète et compositeur. Ed. Jacques Chailley, Paul Imbs, and Daniel Poirion. Paris: Klincksieck, 1982. 117-33. Print.

Badel, Pierre-Yves. "Par un tout seul escondire: Sur un virelai du Buisson de Jeunesse." Romania 17 (1986): 369-79. Print.

Bent, Margaret. "The Machaut Manuscripts Vg, B and E.” Musica disciplina 37 (1983): 53-82. Print.

Binski, Paul, and Stella Panayotova. The Cambridge Illuminations: Ten Centuries of Book Production in the Medieval West. Turnhout: Brepols, 2005. Print.

Cabré, Lluís. "Los enuigs de Jordi de Sant Jordi i l'adaptació del lai líric a la poesia catalana medieval." Estudis de literatura catalana en honor de Josep Romeu $i$ Figueras. Ed. Lola Badia and Josep Massot i Muntaner. 2 vols. Barcelona: Publicacions de l'Abadia de Montserrat, 1986. 2: 183-90. Print.

—. "El conreu del lai líric a la literatura catalana medieval." Llengua \& Literatura 2 (1987): 67-132. Print. 
Cingolani, Stefano. "Joglars, ministrers i xantres a la Corona d'Aragó (segles XIII-XV): Observacions i perspectives de recerca a propòsit d'un diplomatari en curs." Alberni and Ventura 237-68.

Earp, Lawrence. "Machaut's Role in the Production of Manuscripts of His Works." Journal of the American Musciological Society 42 (1989): 461503. Print.

- Guillaume de Machaut: A Guide to Research. New York and London: Garland, 1995. Print.

—. "Vg to 1389: Jean de Berry and Gaston Fébus" and "Vg at the court of Aragon, 1389-1458." The Ferrell-Vogüé Machaut Manuscript. Oxford: DIAMM, 2014, 28-68. Print.

Febrer, Andreu. Poesies. Ed. Martí de Riquer. Barcelona: Barcino, 1951. Print.

Gómez Moreno, Ángel. El prohemio e carta del Marqués de Santillana y la teoría literaria del s. XV. Barcelona: PPU, 1990. Print.

Gómez Muntané, Mari-Carmen. La música en la casa real catalano-aragonesa, 1336-1442. 2 vols. Barcelona: Bosch, 1979. Print.

—. La música medieval en España. Kassel: Reichenberger, 2001. Print

Granson, Oton de. Poésies. Ed. Joan Grenier-Winther. Paris: Champion, 2010. Print.

Kay, Sarah. Parrots and Nightingales: Troubadour Quotations and the Development of European Poetry. Philadelphia: U of Pennsylvania P, 2013. Print.

Lagomarsini, Claudio. "Il Roman de Cardenois e la tradizione manoscritta di Guillaume de Machaut.” Romania 130 (2012): 109-33. Print.

—. "Poesia lirica nel romanzo in prosa: Guillaume de Machaut e l'anonimo Roman de Cardenois." Alberni and Ventura 211-26.

Machaut, Guillaume de. Le Jugement du roy de Behaigne and Remede de Fortune. Ed. and trans. James I. Wimsatt and William W. Kibler, music ed. by Rebecca A. Baltzer. Athens, GA, and London: The U of Georgia P, 1988. Print.

$\longrightarrow$ Le Livre du Voir Dit. Ed. Paul Imbs and Jacqueline Cerquiglini-Toulet. Paris: Le Livre de Poche, 1999. Print.

Marfany, Marta. "La influència de la poesia francesa des d'Andreu Febrer a Ausiàs March.” Estudis Romànics 34 (2012): 259-87. Print.

—_. "Les balades franceses del cançoner català Vega-Aguiló i Oton de Granson; Oliver de Gleu: proposta d'identificació d'un dels poetes del recull." Alberni and Ventura 127-40.

McGrady, Deborah L. Controlling Readers: Guillaume de Machaut and His Late Medieval Audience. Toronto: U of Toronto P, 2006. Print.

Morato, Nicola, and Dirk Schoenaers, eds. Medieval Francophone Literary Culture Outside France: Studies in the Moving Word. Turnhout: Brepols, 2018. Print.

Moscati, Ruggero. Per una storia della Sicilia nell'età dei Martini (appunti e documenti: 1396-1408). Messina: Università degli Studi di Messina, 1954. Print. 
Pagès, Amédée. La poésie française en Catalogne du XIIIe siècle à la fin du XVe. Toulouse and Paris: Privat and Didier, 1936. Print.

Parramon i Blasco, Jordi. Repertori mètric de la poesia catalana. Barcelona: Publications de l'Abadia de Montserrat, 1992. Print.

Plumley, Yolanda. "An 'episode in the South'? Ars subtilior and the Patronage of the French Princes.” Early Music History 22 (2003): 103-68. Print.

- The Art of Grafted Song: Citation and Allusion in the Age of Machaut. Oxford: Oxford UP, 2013. Print.

Roman de Cardenois. Ed. Marcello Cocco. Bologna: Pàtron, 1975. Print.

Roman de Cardenois. Ed. Claudio Lagomarsini, Fabio Zinelli, and Anna Di Fabrizio. Paris: Champion, forthcoming. Print.

Rubió i Lluch, Antoni. Documents per a la història de la cultura catalana migeval. 2 vols. Barcelona: Institut d'Estudis Catalans, 1908-1921, repr. 2000. Print.

Speroni, Gian Battista. "Una rilettura del Roman de Cardenois (a proposito di una recente edizione).” Medioevo Romanzo 4 (1977): 110-34. Print.

Sultan, Agathe. "Ymagner son chant: Présence de la musique chez Froissart." Froissart à la cour de Béarn: L'écrivain, les arts et le pouvoir. Ed. Valérie Fasseur. Turnhout: Brepols, 2009. 305-20. Print.

Torró, Jaume. Sis poetes del regnat d'Alfons el Magnànim. Barcelona: Barcino, 2009. Print.

—. "La poesia cortesana." Història de la Literatura Catalana, Literatura medieval (II). Segles XIV-XV. Dir. Lola Badia. Barcelona: Enciclopèdia Catalana, Editorial Barcino, Ajuntament de Barcelona, 2014. 261-352. Print.

Valero de Holzbacher, Ana-María. "En réhabilitant la mémoire de Guillaume de Machaut." Guillaume de Machaut, poète et compositeur. Ed Jacques Chailley, Paul Imbs, and Daniel Poirion. Paris: Klincksieck, 1982. 41-48. Print.

—. "Elementos histórico-geográficos en el Roman de Passebeauté et Cardenois: Un ejemplo más de la presencia de Cataluña en la novela francesa de los siglos xiv y xv." Boletín de la Real Academia de Buenas Letras de Barcelona 39 (1983-1984): 177-90. Print.

Vicens, Teresa. “Aproximació al món artístic de Maria de Castella.” Capitula facta et firmata: Inquietuds artístiques en el quatre-cents. Ed. Maria Rosa Terés. Valls: Cossetània, 2009. 193-262. Print.

Williams, Sarah J. “An Author's Role in Fourteenth Century Book Production: Guillaume de Machaut's 'livre ou je met toutes mes choses'.” Romania 90 (1969): 433-54. Print.

Zinelli, Fabio. "Il Roman de Cardenois, Guillaume de Machaut e Oton de Grandson tra Francia del sud e Catalogna.” Romania 130 (2012): 294354. Print. 